\title{
EKSPEDISI MILITER BELANDA DI MANDAR 1905-1907
}

\section{THE DUTCH MILITARY EXPEDITION IN MANDAR 1905-1907}

\author{
Abdul Karim \\ Institut Agama Islam Pare-Pare \\ Jln. Amal Bakti No.8, Soreang, Kota Pare-Pare, Sulawesi Selatan, Indonesia \\ karimsejarah@gmail.com
}

Diterima tanggal 4 November 2019

Disetujui tanggal 15 Juni 2020

\begin{abstract}
The Dutch controlled the whole region of Sulawesi from 1906. The authorization of the Dutch was indicated by the change of Mandar's status as a vassal state. The condition was recorded in the report of military expedition of the Dutch government between 1905-1906, which a decisive armed action overthrew the last region in Sulawesi. In this paper, the main problems were how and why the military expedition could be the key to success of the Dutch control over Sulawesi. The study used the historical method which consists of heuristics, criticism, interpretation, and historiography. The results showed that the Dutch military expedition led to the struggle of local elites which the Dutch utilized as political strategy devide et impera. The Dutch which found difficulty dealing with Mandar's decided to ally with some aristocratic groups. Thus, the people of Mandar who were led by I Sendjata and Ammana I Wewang also had to fight the Mandar aristocratic who were on the side of the Dutch East Indies government. Eventually, the Dutch East Indies government was the winner, and the ambition to establish decentralization for creating a single administrative system were achieved.
\end{abstract}

Keywords: military expedition, Mandar, struggle, and local elite.

\begin{abstract}
ABSTRAK
Penguasaan Belanda atas wilayah Sulawesi secara utuh dimulai pada 1906. Otoritas Belanda atas Mandar tampak dari perubahan status Mandar menjadi negara bawahan. Kondisi itu terekam dalam laporan ekspedisi militer pemerintah Hindia Belanda 1905-1906, sebuah aksi bersenjata penentu kejatuhan wilayah terakhir di Sulawesi. Bagaimana dan mengapa ekspedisi militer yang menjadi kunci penguasaan Belanda di seluruh wilayah Sulawesi tersebut dapat berhasil adalah pokok permasalahan dari tulisan ini. Dengan menggunakan metode sejarah yang terdiri atas heuristik, kritik, interpretasi, dan historiografi, permasalahan tersebut akan dibahas dalam tulisan ini. Hasil penelitian menunjukkan bahwa ekspedisi militer Belanda melahirkan pergulatan elite lokal yang dimanfaatkan Belanda untuk diadu domba. Belanda yang kesulitan menghadapi perlawanan rakyat Mandar akhirnya bersepakat dengan sebagian kelompok bangsawan untuk bekerja sama. Dengan demikian, rakyat Mandar yang dipimpin oleh I Sendjata dan Ammana I Wewang juga harus melawan bangsawan Mandar
\end{abstract}

DOI: $10.33652 /$ handep.v3i2.79 
yang berada di pihak pemerintah Hindia Belanda. Pemerintah Hindia Belanda akhirnya menjadi pemenang dan cita-cita desentralisasi untuk membentuk sistem administrasi yang tunggal terlaksana.

Kata kunci: ekspedisi militer, Mandar, perjuangan, dan elite lokal.

\section{A. PENDAHULUAN}

Ekspedisi militer Belanda 1905-1907 berdampak pada status wilayah Mandar dalam sistem administrasi Pemerintah Hindia Belanda. Status wilayah Mandar dalam struktur Pemerintah Hindia Belanda berubah pada 1907. Status Mandar sebagai onderafdeling ${ }^{l}$ dari wilayah Afdeling Pare-Pare menjadi Afdeling Mandar yang berdiri sendiri sejak 1909 (Vorstman 1924:22). Ekspedisi militer itu tercatat jelas dalam laporan ekspedisi militer Belanda di Gowa, Ajatappareng, Massenrempulu, dan Mandar (Dienst van Oorlog in Nederlandsch Indie [D.v.O in N.I.] 1916:245-380). Ekspedisi itu bertujuan untuk mengubah status Mandar dari negara sekutu menjadi negara bawahan. Negara sekutu merupakan status kerajaan yang tidak diperintah langsung oleh Pemerintah Hindia Belanda tetapi menjalin kerja sama terutama pada bidang ekonomi. Negara bawahan berarti kerajaan tersebut telah dikuasai

\footnotetext{
1 Onderafdeling adalah unit administratif dalam struktur pemerintahan Hindia Belanda. Onderafdeling berada di bawah afdeling dan afdeling dibawah residentie. Onderafdeling dipimpin oleh controleur, afdeling dipimpin oleh asisten residen, dan residentie dipimpin oleh resident. Dewasa ini onderafdeling indentik dengan kecamatan, afdeling identik denga kabupaten, dan residentie identik dengan provinsi.
}

sepenuhnya, segala hal yang berkaitan dengan politik dan ekonomi diatur langsung oleh Pemerintah Hindia Belanda. Hal itu juga sejalan dengan misi utama dari Pemerintah Hindia Belanda yakni politik pasifikasi atau sering kali disebut sebagai Pax Neerlandica.

Strategi politik yang dilakukan oleh Pemerintah Hindia Belanda merupakan sebuah usaha untuk menguasai wilayah Nusantara secara penuh, baik Sumatra, Jawa, Kalimantan, Sulawesi, Maluku, maupun wilayah lainnya. Sulawesi menjadi salah satu wilayah konsentrasi penaklukan dalam usaha penguasaan tersebut. Kerajaan Gowa menjadi salah satu wilayah yang dikuasai pada 1824 dan menjadi wilayah pemerintahan langsung Belanda (Kartodirdjo 1973:263). Kerajaan ini nampaknya lebih awal menjadi wilayah kekuasaan karena merupakan pusat kekuasaan dan perekonomian Sulawesi Selatan pada abad XIX.

Berbeda dengan Kerajaan Gowa, kerajaan-kerajaan di Mandar ${ }^{2}$ pada 1848 belum menjadi wilayah kekuasaan Pemerintah Hindia Belanda (Kartodirdjo 1973:297). Kondisi itu

\footnotetext{
2 Mandar merupakan sebuah daerah administratif pada masa pemerintah Hindia Belanda tetapi juga dikenal sebagai nama sebuah suku di Sulawesi. Sekarang dikenal sebagai wilayah Sulawesi Barat.
} 
menunjukkan bahwa kerajaan-kerajaan di Mandar masih menjadi wilayah yang sulit untuk ditaklukkan. Meskipun sulit, Pemerintah Hindia Belanda tetap berusaha karena Mandar memiliki peran cukup penting dalam bidang politik maupun ekonomi, utamanya di wilayah bagian barat Sulawesi.

Ditinjau dari sisi geografis, Mandar berada di pelintasan jalur perdagangan pantai barat Sulawesi. Posisi ini menunjukkan bahwa Mandar memiliki peran penting terutama menghubungkan bagian utara dan selatan Sulawesi. Akses ke wilayah-wilayah itulah yang diinginkan oleh Pemerintah Hindia Belanda.

Mandar sebagai wilayah penting bagi Belanda menjelma menjadi pos pengawasan terhadap wilayah-wilayah di sekitarnya. Belanda bercokol di Majene dan menjadikannya sebagai pusat pemerintahan di Mandar (Ibu Kota Onderafdeling Mandar). Setelah ekspedisi militer Belanda 1905-1907, Majene dipilih sebagai ibu kota Afdeling Mandar karena posisinya yang sangat strategis dan memiliki pelabuhan yang cukup berperan di pantai barat Sulawesi. Posisi Majene menjadi sangat strategis karena berada di tengah-tengah wilayah Mandar yang dapat menghubungkan wilayah pedalaman dan wilayah pesisir.

Keberadaan Belanda yang telah ada sebelum ekspedisi militer kemudian menjadi pemicu pergolakan rakyat Mandar terhadap Belanda. Selanjutnya, kebijakan Belanda juga mendesak rakyat Mandar melakukan gerakan perlawanan. Resistensi tersebut kemudian menyebar sehingga menimbulkan perlawanan di Campalagian, Majene, Pamboang dan akhirnya Mamuju. Gerakan di Campalagian yang dimotori oleh I Sendjata menjadi awal dari gerakan ekspedisi militer Belanda.

Gerakan itu juga terjadi di wilayah Sulawesi Selatan di periode yang sama. Wilayah-wilayah tersebut meliputi Bone, Soppeng, seluruh wilayah konfederasi Ajatappareng, Luwu, dan seluruh wilayah Massenrempulu (Enrekang dan sekitarnya). Penguasaan atas wilayah Sulawesi bagian selatan menjadi sangat penting bagi pemerintah Hindia Belanda. Wilayah-wilayah tersebut penting untuk menyokong Makassar sebagai wilayah pusat perekonomian maupun politik. Makassar sebagai pusat harus diamankan dengan cara menaklukkan wilayah-wilayah penyokongnya.

Usaha penaklukkan membuat ekspedisi militer Belanda menjadi kajian yang cukup menarik karena menimbulkan beberapa pertanyaan, yakni apa yang menjadi sebab utama dari ekspedisi militer itu, bagaimana jalannya ekspedisi militer tersebut, bagaimana respons elite lokal atas jalannya ekspedisi, dan apa dampak dari ekspedisi militer tersebut. Pertanyaan-pertanyaan ini patut diajukan untuk mengkaji secara mendalam kondisi Mandar pada 19051907. Periode yang diajukan oleh kajian ini memang cukup singkat, hanya dua tahun. Namun, periode 
tersebut membawa pengaruh yang cukup signifikan terhadap alur sejarah Mandar terutama setelah kolonialisasi Belanda.

Tulisan ini bertujuan untuk mengungkap ekspedisi militer Belanda dan peran elite lokal dalam ekspedisi tersebut serta dampak yang terjadi setelah ekspedisi militer Belanda. Apakah ekspedisi militer membawa perubahan yang signifikan terhadap kerajaan-kerajaan di Mandar terutama yang menyangkut proyek desentralisasi yang diusulkan oleh De Graff pada awal abad XIX.

Untuk mengungkap persoalan di atas, penulis meninjau beberapa tulisan terkait sejarah sosial-politik Mandar, ekspedisi militer Belanda khususnya di periode awal abad XX saat negara kolonial menguat, dan kajian politikbudaya tentang elite lokal.

Materi pertama antara lain dikaji oleh Darmawan Mas'ud Rahman (1988) dalam Puang dan Daeng Kajian Sistem Nilai Budaya Orang Balanipa Mandar. Disertasi ini menggambarkan bentuk pemerintahan tradisional yakni pada masa awal (Tomakaka) dan pada masa puncaknya (Mara'dia). Karya lain ditulis oleh Edward L. Poelinggomang (2004) dalam Perubahan Politik dan Hubungan Kekuasaan: Makassar, 1906-1942 tidak jauh berbeda, yakni menggagas perubahan sistem pemerintahan lokal menjadi sistem pemerintahan kolonial di Sulawesi. Karya ini juga mengungkap resistensi antara rakyat Sulawesi dan Pemerintah Hindia-Belanda akibat perubahan itu.
Perubahan kondisi politik tersebut merupakan salah satu dampak yang ditimbulkan ekspedisi militer Belanda yang menginginkan sistem desentralisasi dan penguasaan penuh atas seluruh wilayah di Sulawesi. Artikel ini tidak hanya membahas tentang perubahan sistem pemerintahan saja tetapi juga akan membahas adanya peran elite lokal dalam melawan dan mendukung ekspedisi militer Belanda yang pada akhirnya mengubah sistem pemerintahan.

Tulisan tentang ekspedisi militer dan perubahan sistem pemerintahan juga telah ditulis oleh Abd. Karim dalam Political Contestation, Political Elite Contestation of Balanipa Kingdom and Netherland Colonial Government in 1870-1905 (2018) dan Jatuhnya Kerajaan Balanipa: Penataan Wilayah Mandar 1905-1942 (2018). Kedua karya tersebut mengungkapkan peran elite lokal tetapi tidak mengkaji lebih dalam soal ekspedisi militer. Artikel ini lebih dalam membahas dan memunculkan sosok I Sendjata yang tidak dimunculkan oleh kedua karya tersebut.

Selanjutnya karya Muhammad Amir Gerakan Petta Barang di Daerah Bugis pada 1906-1913 (2017) dan Perlawanan Sawitto terhadap Belanda di Sulawesi Selatan pada 1905-1906 (2018). Berikutnya karya Abd. Latif (2014) yang berjudul Diplomasi dan Ekspedisi Militer Belanda terhadap Tiga Kerajaan Lokal di Sulawesi Selatan 1824-1860 (2014). Ketiga karya tersebut pada umumnya mengkaji 
tentang perlawanan rakyat Sulawesi Selatan terhadap Belanda tetapi tidak memunculkan peran elite lokal yang mendukung Belanda. Karya Amir menyebutkan bahwa Belanda berhasil menangkap Lapatu dengan bantuan penduduk dan kepala kampung. Hanya saja, kepala kampung tidak termasuk dalam elite lokal karena kepala kampung bisa dijabat oleh siapa saja selain bangsawan. Artikel ini mengungkap bahwa elite yang dimaksud adalah bangsawan itu sendiri bahkan antara satu elite dengan elite lainnya mempunyai hubungan darah.

Ekspedisi militer memicu pergulatan elite lokal yang menggambarkan perbedaan antara pihak yang sepakat dan menentang Pemerintah Hindia Belanda. Kondisi itu kemudian menimbulkan peristiwa-peristiwa perlawanan rakyat Mandar terhadap Belanda. Kondisi resistensi itu kemudian membawa Mandar ke dalam pusaran konflik yang membuat Belanda melakukan tindakan militer. Salah satunya yakni membakar kampung dan menangkap rakyat yang diduga terlibat dalam gerakan perlawanan itu. Ekspedisi militer Belanda pada akhirnya melahirkan kompleksitas dalam historiografi Mandar.

Kompleksitas yang dimaksud yakni lahirnya dua kubu elite lokal yang proBelanda dan kontra Belanda. Narasi sejarah Mandar akhirnya menjadi rumit karena muncul dua sudut pandang berbeda. Pertentangan antara pihak yang pro dan kontra terhadap Pemerintah Belanda menjadi kajian utama dalam historiografi Mandar terutama periode ekspedisi militer Belanda. Oleh karenanya, kajian ini menjadi sangat penting untuk membangun sudut pandang dalam menyikapi peristiwa ekspedisi militer.

Kajian ini juga akan memperjelas peristiwa-peristiwa terkait usaha struktural Belanda yang ingin menguasai Mandar secara penuh dan mengubah status Mandar sebagai "negara bawahan". Meskipun usaha itu juga dilakukan di wilayah lain, tetapi ekspedisi militer yang dilakukan oleh Belanda di Mandar praktis mengubah sistem budaya, politik, hingga ekonomi di wilayah itu. Perubahan yang paling menonjol yakni pada bidang politik.

Sistem politik yang berubah dipengaruhi oleh peristiwa ekspedisi militer. Pergulatan elite lokal juga ikut dalam peristiwa itu. Ekspedisi militer dan munculnya elite lokal yang menolak Belanda di Mandar melahirkan perlawanan. Perlawanan itu merupakan bentuk dari sikap penolakan rakyat Mandar terhadap kolonialisasi Belanda yang pada akhirnya akan membuat rakyat menderita. Kaum bangsawan menjadi motor penggerak utama gerakan perlawanan rakyat. Namun di sisi lain, hadir pula bangsawan yang berada di pihak Belanda.

Ekspedisi militer Belanda merupakan salah satu usaha pemerintah Hindia Belanda untuk menjalankan proyek desentralisasi. Furnivall melihat proyek itu memiliki dua prinsip yakni efisiensi dan otonomi (Furnivall 
2009:279). Prinsip pelaksanaan pemerintahan itu bertujuan untuk memaksa kerajaan-kerajaan lokal bekerja sama dengan Belanda dengan iming-iming pengaturan wilayah sendiri. Scholten juga memandang ekspedisi militer yang terjadi di luar wilayah Jawa utamanya Sulawesi merupakan usaha Belanda untuk mengontrol penuh wilayah Hindia Belanda (Locher-Scholten 1994:95).

Ekspedisi militer menjadi puncak dari pertentangan elite lokal Mandar dan Belanda yang memiliki kepentingan masing-masing. Belanda dengan penerapan prinsip efisiensi dan otonomi untuk mencapai tujuan memperoleh keuntungan pada sektor ekonomi. Elite Mandar yang pro terhadap Belanda memiliki kepentingan praktis untuk bekerja sama dengan Belanda. Sementara elite lokal yang kontra terhadap Belanda memiliki kepentingan mengusir Belanda dari Mandar.

Upaya Belanda tersebut dinilai Furnivall sebagai pembangunan sistem administrasi tunggal untuk menggantikan administrasi ganda yang sebelumnya tunggal dengan tujuan akhir membentuk sistem perekonomian yang efisien (Furnivall 2009:279).

Kondisi itu akan dikaji lebih mendalam melalui kasus ekspedisi militer Belanda di Mandar. Pada tulisan ini, ekspedisi militer Belanda ditempatkan sebagai bagian dari imperialisme modern (Locher-Scholten 1994:91).
Imperialisme modern banyak dikonsepsikan bertujuan untuk menyebarluaskan pengaruh barat (modern) ke wilayah timur (kuno) dengan kata lain, imperialisme membawa misi modernisasi. Namun, mengacu pada pendapat LocherScholten (1994:92), tulisan ini akan menempatkan usaha modernisasi yang dilakukan oleh Pemerintah Hindia Belanda hanya sebagai "topeng" saja untuk menanamkan kekuasaannya di Nusantara pada umumnya dan di Sulawesi pada khususnya.

Tujuan utama Pemerintah Hindia Belanda untuk menguasai secara penuh nampak dari usahanya untuk membuat legitimasi melalui penandatanganan kontrak-kontrak pendek hingga akhirnya tindakan militer yang dikenal dengan ekspedisi militer Belanda.

Proses yang dilalui oleh Pemerintah Hindia Belanda dalam penguasaannya atas Mandar merupakan proses dari imperialisme modern. Di mana dalam prosesnya, terjadi penandatanganan kontrak, ekspedisi militer dan penguasaan penuh atas wilayah Mandar. Nampaknya, Belanda juga tidak berniat untuk melakukan modernisasi terhadap wilayah Mandar tetapi hanya berutujuan untuk menguasai wilayah tersebut demi kepentingan politik dan ekonomi di masa berikutnya.

\section{B. METODE}

Tulisan ini menggunakan metode penelitian sejarah yakni heuristik, kritik, interpretasi dan historiografi. 
Tujuan penggunaan metode penelitian sejarah untuk meminimalisasi, meskipun tidak dapat dihindari, subjektivitas penulisan. Hal itu terjadi karena dalam pemecahan fakta sejarawan memilih sebuah tema berdasarkan kesenangan dan minatnya sendiri. Bukan hanya itu, tetapi periode dan rumusan masalah serta analisis terhadap sebuah peristiwa itu juga berdasarkan minat dari sejawaran itu sendiri (Southgate 2001:68). Memilih pun merupakan sebuah subjektivitas. Oleh karena itu penggunaan metode sejarah menjadi sangat penting.

Langkah pertama yakni heuristik. Proses ini bertujuan untuk mencari sumber-sumber terkait dengan kajian. Sumber-sumber yang penulis kumpulkan berupa sumber tertulis diperoleh dari Badan Arsip Nasional dan Daerah Sulawesi Selatan. Sumbersumber yang digunakan tidak hanya sumber kolonial tetapi juga sumbersumber lokal berupa lontara'. Seluruh sumber yang berhubungan dengan aktivitas politik pemerintah kolonial di antaranya, Memorie van Overgave asisten W.J. Leyds selama bertugas di Mandar, kontrak-kontrak antara Mandar-Belanda termasuk Korte Verklaring, Ikhtisar Politik Pemerintah Kolonial Belanda 1839-1848, Surat Edaran Gubernur Sulawesi A. Couvreur, Nota van Toelichting Betreffende het Landschap Balangnipa Tijd. LIV 503-535 (1912) dan lontara' Mandar yang telah ditransliterasi dan diterjemahkan.
Tahap selanjutnya yakni kritik sumber. Penulis menyeleksi beberapa sumber-sumber. Seleksi sumber kolonial ketat dengan memperbandingkan antara sumber lokal (lontara' pattodioloang) dan sumber kolonial (laporan ekspedisi militer). Kedua sumber tersebut cukup berseberangan, Lontara' menyebut elite lokal (I Sendjata dan Ammana I Wewang) yang melawan Belanda sebagai pahlawan dan laporan kolonial menyebutnya sebagai "rampokers" terkadang disebut juga pemberontak.

Namun perbedaan keterangan itu justru memberikan petunjuk karena Lontara' tidak menjelaskan secara detail peristiwa terutama mengenai waktu sedangkan laporan militer Belanda memberikan keterangan waktu yang cukup baik. Oleh karenanya, kedua sumber tersebut dikombinasikan untuk mengurai peristiwa ekspedisi militer. Selain itu, lontara' digunakan untuk melihat transformasi kisah ekspedisi militer di Mandar dengan kata lain, lontara' dapat dijadikan sebagai sumber sejarah meskipun kebanyakan berisi kisah yang kurang dapat diterima oleh akal (Karim 2019:14).

Tahap ketiga yakni interpretasi. Proses ini merupakan tahap utama penulisan sejarah karena pada tahap ini, data yang telah ditemukan diolah untuk dijadikan fakta. Penulis pada tahap ini akan sangat menunjukkan subjektivitas penulis. Tidak menutup kemungkinan penulis akan membangun klasifikasi elite yang berposisi sebagai "pengkhianat" dan sebagai "pahlawan". 
Tahap terakhir yakni historiografi yakni tahap di mana fakta-fakta yang telah ditemukan ditulis menggunakan kaidah penulisan sejarah dan tentu saja, dengan menggunakan aturan-aturan penulisan karya ilmiah. Penulis akan mencoba mengurai kondisi Mandar pada zaman kolonial dan akan berfokus pada penggambaran peristiwa pada periode 1905-1907 terutama pada kasus ekspedisi militer Belanda.

\section{HASIL DAN BAHASAN}

Mandar lebih dikenal sebagai kesatuan suku di wilayah Sulawesi Barat saat ini. Kesatuan suku itu tidak berdiri sendiri sebagai kesatuan yang homogen tetapi sangat heterogen. Kesatuan itu melingkupi beberapa suku-suku yang mendiami wilayah ini. Namun, apabila ditinjau dari sudut pandang geopolitik, Mandar dikenal sebagai wilayah yang terbentang dari Paku (Kabupaten Polewali Mandar) sampai Suremana (Kabupaten Mamuju Utara).

Batas-batas wilayah tersebut terbentuk berdasarkan latar sejarah yang telah dilalui. Wilayah Mandar beberapa kali mengalami perubahan status administrasi mulai dari onderafdeling sampai afdeling. Namun, pada tahun 1912 sebuah catatan menyebutkan bahwa wilayah Mandar berada pada $2^{\circ} 50^{\prime}$ L.S dan $118^{0} 54^{\prime}$ ' B.T. dan $119^{\circ} 20^{\prime}$ B.T. Luas wilayah ditaksir sekitar 2000 km² (Boom 1912:503). Apabila garis lintang dan bujur ini ditarik, maka batas itu persis dengan batas wilayah yang sekarang.

Mandar sebagai kesatuan politik dikenal sebagai wilayah yang terdiri atas dua konfederasi yakni Pitu Ulunna Salu (tujuh kerajaan di wilayah pegunungan) dan Pitu Ba'bana Binanga (tujuh kerajaan di pesisir. Dua kesatuan itu merupakan konfederasi kerajaan-kerajaan di Mandar. Pitu Ulunna Salu terdiri atas Kerajaan Rantebulahan, Aralle, Mambi, Bambang, Matangnga, Messawa, dan Tabulahan. Adapun Pitu Ba'bana Binanga terdiri atas Kerajaan Balanipa, Banggae, Pamboang, Sendana, Tappalang, Mamuju dan Binuang. Kedua konfederasi itu kemudian bersepakat untuk membentuk persekutuan yang dikenal dengan Mandar. Kesepakatan itu tertuang dalam perjanjian Tammejarra II yang dilaksanakan di Luyo pada 1610 (Poelinggomang 2012:51-52).

Konfederasi Mandar tersebut dipimpin oleh Kerajaan Balanipa. Dengan kata lain, segala sesuatu yang berkaitan dengan hubungan politik dan ekonomi kerajaan-kerajaan di Mandar akan diwakili oleh Balanipa. Kerajaan ini disebut juga sebagai "bapak" untuk 

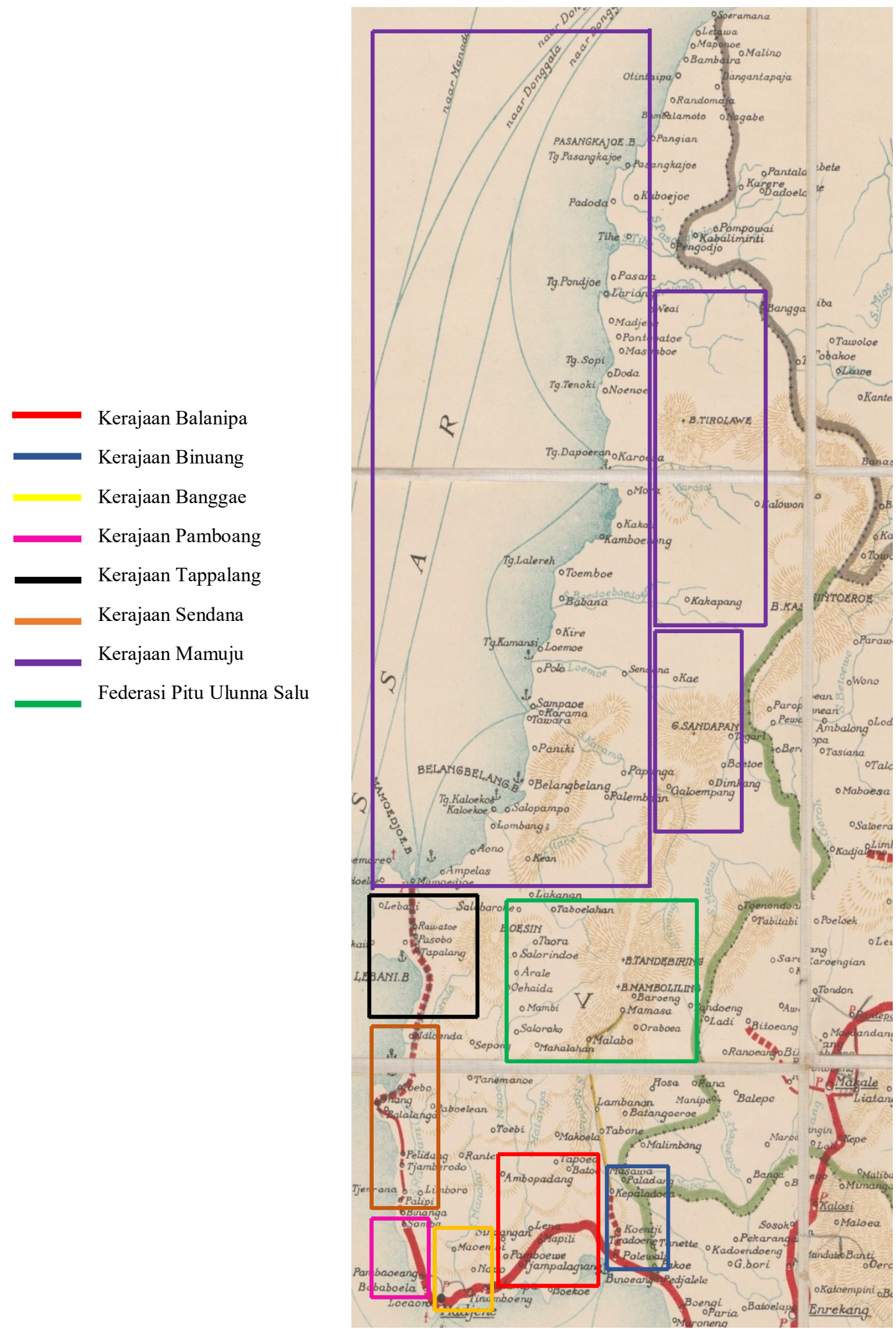

Peta 1. Wilayah Mandar. Sumber: https://digitalcollections.universiteitleiden.nl/view/item/ 817268?solr_nav\%5Bid\%5D=af5af995e6d996511abf\&sol__nav\%5Bpage\%5D=0\&solr_nav\%5Boffset\%5D=15. 
merepresentasikan bahwa Balanipa adalah pemimpin. Untuk lebih jelasnya dapat dilihat melalui peta berikut:

Status Kerajaan Balanipa sebagai pemimpin dari kedua konfederasi tersebut menjadi sangat krusial. Oleh karenanya, posisi mara'dia ${ }^{3}$ Balanipa menjadi sangat diminati oleh kalangan bangsawan yang tergabung dalam konfederasi. Tentu saja dalam pemilihan raja Balanipa harus melalui proses seleksi dan kriteria tertentu. Kondisi itu terkadang menimbulkan konflik internal karena beberapa elite lokal berambisi untuk menjadi raja Balanipa.

Di sisi lain, Belanda juga sangat ingin menguasai wilayah Mandar. Berdasarkan Laporan Politik Pemerintah Hindia Belanda, Mandar tidak pernah dikuasai setidaknya hingga 1848 karena kegigihan mereka yang menolak kedatangan Belanda (Kartodirdjo 1973:289). Penolakan yang dilakukan oleh rakyat Mandar pada akhirnya dapat diredam oleh Belanda pada 1850.

Usaha yang dilakukan oleh Belanda untuk mengatasi penolakan itu yakni dengan membuat kontrak politik dengan kerajaan-kerajaan Mandar. Kontrak itu kemudian menggiring Mandar ke dalam perangkap yang disiapkan oleh pemerintah Hindia Belanda tetapi status kerajaan masih sebagai negara berdaulat atau Belanda menyebutnya sebagai negara sekutu.

\footnotetext{
3 Mara'dia merupakan gelar yang diberikan bagi seseorang yang berposisi sebagai raja di kerajaan-kerajaan Mandar.
}

Hal ini berbeda dengan kerajaankerajaan yang sepakat dengan perjanjian Bungayya secara legal berada di bawah kontrol langsung Pemerintah Hindia Belanda atau Belanda menyebutnya sebagai negara bawahan.

Periode awal abad XX menjadi masa yang cukup menentukan bagi pemerintah Hindia Belanda karena pemerintah mulai menjalankan proyek desentralisasi dan menguasai seluruh wilayah Hindia Belanda secara utuh.

Untuk mewujudkan proyek desentralisasi, Belanda melancarkan ekspedisi militer di Mandar. Pembahasan ekspedisi militer berikut akan mengkaji latar belakang ekspedisi militer Belanda ke Mandar, jalannya ekspedisi, sikap elite Mandar terhadap ekspedisi, dan akhir ekspedisi.

\section{Latar Belakang Ekspedisi Militer Belanda ke Mandar}

Wilayah Mandar dalam periode 1900an sedang mengalami konflik internal antar-elite lokal dalam perebutan tahta Kerajaan Balanipa. Tentu saja kondisi ini sangat menguntungkan bagi Belanda dalam usaha penguasaan wilayah Mandar.

Konflik awal terkait dengan konteks perebutan tahta dan kontestasi yang terjadi pada periode 1905-1906 bermula dari keinginan I Mandawari menjabat sebagai raja Balanipa dan menandatangani kontrak dengan Belanda pada tahun 1870 (Sinrang 1994:156). Sikap I Mandawari kemudian ditolak oleh sepupunya 
sendiri yang bernama Tokape atau dikenal juga dengan nama I Baso' dan merupakan anak dari mantan raja Balanipa yang bernama Tomate di Lekopa'dis (Syah 1992:100).

Penolakan Tokape kemudian berwujud sikap perlawanan terhadap Pemerintah Hindia Belanda. Pasukan Tokape kerap kali melakukan penyerangan kepada kapal-kapal Pemerintah Hindia Belanda yang berlalu-lalang di perairan Mandar (pantai barat Sulawesi/Celebes). Selain itu, Tokape juga terang-terangan menolak kedatangan Gubernemen Celebes dan pada tahun 1872 berhasil menganti I Mandadawari sebagai raja Balanipa. Pergantian itu juga didukung oleh Hadat Mandar ${ }^{4}$ (Sinrang 1994:150).

I Mandawari yang turun tahta akhirnya menyingkir ke Makassar untuk memperoleh perlindungan dari Pemerintah Hindia Belanda. Dalam kondisi itu, Pemerintah Hindia Belanda juga tidak mengakui Tokape menjadi raja Balanipa sehingga masih menganggap bahwa I Mandawari sebagai raja Balanipa.

Kondisi tersebut memaksa Belanda melancarkan ekspedisi militer untuk membantu I Mandawari dan melawan

${ }^{4}$ Hadat Mandar merupakan sebuah lembaga dari sistem pemerintahan di Kerajaankerajaan di Mandar yang dikenal dengan $A d a$ ' Sappulo Sokko' (sepuluh anggota lembaga adat). Tugas utamanya adalah mengambil keputusan-keputusan penting terkait jalannya pemerintahan termasuk menurunkan raja dari tahtanya berdsarkan rekomendasi yang diterima.
Tokape. Ekspedisi yang dipimpin oleh Letnan Kolonel van Daalen (Boom 1912:503-535) akhirnya berhasil menangkap Tokape dan diasingkan ke Pacitan pada 1873 (Hanoch 2006:36). Tertangkapnya Tokape membuat I Mandawari diangkat kembali sebagai Raja Balanipa oleh Pemerintah Hindia Belanda dan atas persetujuan Hadat Mandar. Kondisi itu menunjukkan bahwa Belanda telah berada di posisi yang sangat menguntungkan dalam usahanya menguasai wilayah Mandar secara utuh.

Selanjutnya sejak tertangkapnya Tokape pada 1873, Pemerintah Hindia Belanda berusaha membentuk wilayah Mandar dengan melakukan perjanjian pendek dan panjang. Selanjutnya merancang pembagian daerah dan menjadikan Mandar sebagai negara bawahan, tidak lagi sebagai negara sekutu pada 1906. Kondisi berupa penandatanganan Korte Verklaring dan pengakuan kerajaan terhadap pemerintah Hindia Belanda sebagai pemerintahan resmi juga terjadi di seluruh wilayah Sulawesi Selatan pada 1906. Ekspedisi militer merupakan aksi bersenjata pemerintah kolonial untuk menguasai seluruh wilayah Sulawesi Selatan.

Ekspedisi militer dilakukan di beberapa kerajaan yang berstatus sebagai "negara aliansi" yakni Bone, Luwu, Soppeng, Gowa, Ajatappareng, Masenrempulu, dan Mandar (D.v.O in N.I. 1916:245). Pemerintah kolonial Belanda memulai persiapan ekspedisi di Bone pada 18 Oktober 1904-14 Juni 
1905, berangkat 14 Juni sampai 13 Juli 1905, berikutnya pasukan dari Batavia, Semarang dan Surabaya diberangkatkan ke Bone pada 13 Juli sampai 18 Juli 1905. Pasukan ekspedisi itu berada di bawah komando S.S. van Riemsdijk. Pasukan itu mendarat di Patiro pada 19 Juli sampai 26 Juli 1905 (Michielsen 1915:31). Ekspedisi militer dilakukan oleh Pemerintah kolonial Belanda secara bertahap di beberapa tempat. Pasukan tidak hanya mendarat dan bersiaga di Patiro tetapi juga di Bajoe pada 27 Juli sampai 28 Juli 1905. Hal itu dilakukan untuk menaklukkan Watampone sebagai ibu kota. Penaklukkan itu terjadi pada 30 Juli sampai 21 Agustus 1905. Ekspedisi itu menyasar wilayah Balangnipa Sinjai yakni pada 9 Agustus sampai 18 Agustus 1905 (Michielsen 1915:54).

Pemerintah kolonial Belanda pada tahun yang sama juga melancarkan ekspedisi militernya ke Luwu. Pada 10 September 1905 Belanda melancarkan ultimatum dan mendaratkan pasukan di Balandai pada 11 September 1905, ekspedisi tersebut menyebar luas ke wilayah Luwu sampai ke perbatasan Toraja. Ekspedisi itu kemudian berakhir pada 1 Agustus 1906 di bawah pimpinan Kapten Infantri A.W.A Michielsen (Michielsen 1915:1).

Pasukan Belanda mendarat di ParePare pada 26 April 1905, jumlah pasukan sebanyak sembilan batalion. Tiga batalion pasukan Belanda dan enam batalion dari Makassar, sasaran utamanya adalah kerajaan-kerajaan Ajatappareng (Sidenreng, Rappang,
Suppa, dan Sawitto) (D.v.O in N.I. 1916:71). Enam batalion Pasukan Belanda kemudian berangkat ke Rappang, Enrekang, dan Kalosi pada tanggal 26 September 1905 (D.v.O in N.I. 1916:83).

Ekspedisi militer Belanda memberi dampak penguasaan wilayah-wilayah tersebut. Makassar dan Bugis merupakan wilayah utama yang menjadi sasaran karena kedua wilayah ini merupakan wilayah pusat dari aktivitas politik dan ekonomi di Sulawesi pada saat itu. Usaha pasifikasi yang dilakukan Belanda membuat perlawanan rakyat semakin gencar karena rakyat Sulawesi Selatan saat itu sadar bahwa mereka akan dikuasai secara penuh apabila ekspedisi itu berhasil.

Akhirnya pada 22 November 1905, Belanda juga melancarkan ekspedisi militer gelombang pertama ke Mandar dan pertama kali mendarat di Campalagian. Ekspedisi itu dipimpin oleh Letnan Gusdorf (D.v.O in N.I. 1916:369). Di saat yang bersamaan, di Campalagian juga terjadi konflik antara I Sendjata dan Rammang. Kondisi itu akhirnya dimanfaatkan oleh Belanda dan lebih mendukung Rammang menjadi mara'dia Campalagian. I Sendjata pada akhirnya melakukan penolakan dan perlawanan kepada pasukan Belanda. Alasan lainnya adalah I Sendjata memang tidak pernah ingin bekerjasama dengan Belanda dalam hal apapun. 


\section{Perlawanan Rakyat Mandar} Menentang Ekspedisi Militer Belanda

Kerajaan-kerajaan Mandar pada periode 1905-1906 belum berstatus sebagai negara bawahan tetapi masih sebagai negara sekutu. Sikap kerajaankerajaan di Mandar yang tidak ingin tunduk kepada pemerintah Hindia Belanda membuat statusnya masih sebagai negara sekutu. Bahkan sikap itu tidak berubah semenjak Perjanjian Bungayya ditandatangani. Usaha pasifikasi yang dilakukan oleh Belanda bertujuan untuk menguasai kerajaankerajaan yang masih berstatus sebagai negara sekutu dan mengubahnya menjadi negara bawahan.

Strategi awal yang dilakukan oleh Belanda untuk menguasai Mandar yakni mengadakan perjanjian politik dengan Kerajaan Balanipa (wakil Mandar) pada 9 Juni 1905. Pihak Mandar diwakili oleh I Mandawari dan Belanda diwakili oleh George Brugman (ANRI 1906:No. 662). Kontrak tersebut secara umum merupakan pengakuan Mandar terhadap pemerintah Hindia Belanda. Pengakuan itu memberikan tanda bahwa Mandar telah dikuasai.

Penempatan seorang pejabat Belanda di Mandar, merupakan legitimasi awal dari kekuasaan Belanda. Akan tetapi, di sisi lain, kekuasaan atas rakyat masih dipegang oleh Kerajaan Balanipa. Status kerajaan saat itu tidak sepenuhnya hilang. Kerajaan-kerajaan Mandar masih berdiri dan masih memiliki mara'dia (raja).
Legitimasi tersebut nampak dari intervensi Belanda terhadap kerajaan di Mandar untuk membayar pajak. Dua kerajaan yang cukup bermasalah dengan pembayaran pajak yakni Kerajaan Sendana dan Tappalang. Kedua Kerajaan ini menolak untuk membayar pajak retribusi yang dikenakan kepada penduduk (D.v.O in N.I. 1916:367)

Pemerintah Hindia Belanda memanggil kedua pemimpin kerajaan untuk berunding dan memperbarui kontrak. Akan tetapi, mereka menolak untuk hadir dan akibatnya pada 3 Oktober 1905 Pa'bicara Kagang ditangkap (D.v.O in N.I. 1916:368).

Sikap Kerajaan Sendana dan Tappalang yang menolak untuk berunding membuat Ekspedisi Militer Belanda tetap berjalan sampai ke wilayah Kerajaan Sendana dan Kerajaan Tappalang. Sayangnya tidak ada perlawanan berarti dari kedua kerajaan itu dan akhirnya Belanda dengan mudah bercokol di wilayah Kerajaan Sendana dan Kerajaan Balanipa. Selain itu, Belanda juga beralibi mengamankan wilayah tersebut sehingga pasukan Belanda tidak mengalami gangguan berarti.

Penguasaan dan penempatan pasukan Belanda di Kerajaan Sendana dan Tappalang karena munculnya beberapa potensi konflik di beberapa tempat yang dapat mengancam kedudukan Belanda di Mandar dalam usaha penaklukkannya. Usaha Belanda menaklukkan Mandar merupakan salah satu bagian dari proyek besar Belanda 
dalam membentuk negara kolonial. Meminjam istilah Ricklefs, usaha ini disebut (the creation of a colonial state).

Ekspedisi itu bertujuan untuk melaksanakan proyek desentralisasi yang diusulkan oleh De Graaf (Furnivall 2009:283). Proyek tersebut diajukan oleh De Graaf untuk mencapai penguasaan secara penuh wilayahwilayah yang statusnya masih sebagai negara sekutu. Selanjutnya, artikel ini mengungkap proses penaklukan Mandar oleh Belanda. Usaha Belanda itu kemudian mendapat respons dari masyarakat Mandar yang tidak ingin menjadi bawahan langsung dari pemerintah Hindia Belanda.

\section{a. Perlawanan I Sendjata di Mandar}

Sikap orang Mandar yang tidak ingin menjadi bawahan Pemerintah Hindia Belanda sangat nampak pada periode 1905-1907. Sikap tersebut berwujud penolakan terhadap pasukan Belanda yang datang ke Mandar dengan dalih mengamankan wilayah Mandar atas permintaan Mara'dia Balanipa I Mandawari.

Sebelum ekspedisi militer Belanda dilancarkan ke Campalagian, terjadi konflik internal antara bangsawan di wilayah ini. Konflik tersebut yakni perebutan tahta raja. Konflik tersebut berawal dari pengangkatan Rammang sebagai mara'dia (raja) Campalagian menggantikan I Tjalla yang meninggal sebagai Mara'dia Campalagian. Rammang merupakan cucu dari I Mandawari. Campalagian merupakan wilayah bawahan dari Kerajaan Balanipa berstatus wilayah vasal. Wilayah itu dipimpin juga oleh seorang mara'dia (raja).

Pengangkatan Rammang sebagai Raja ditolak oleh I Sendjata yang menyatakan dirinya lebih berhak untuk diangkat sebagai raja karena merupakan anak dari La Tonga E. Selain itu, Penolakan I Sendjata atas keputusan tersebut disebabkan oleh penobatan Rammang sebagai mara'dia oleh Pemerintah Hindia Belanda dan I Mandawari sebagai Mara'dia Balanipa. Hal itu dinilai tidak sesuai dengan adat yang berlaku di Mandar. Oleh karenanya, I Sendjata melawan keputusan itu dengan mendapat dukungan dari Mara'dia Binuang beserta 20-30 bangsawan (ANRI 1905: No.476). I Mandawari tidak dapat berbuat banyak karena I Sendjata memang berhak menjadi mara'dia Campalagian karena dia merupakan anak dari raja Campalagian yakni La Tonga E (D.v.O in N.I. 1916:367).

Konflik tersebut tidak terselesaikan. Bahkan, controleur dan Mara'dia Balanipa memperoleh surat bahwa I Sendjata dan Mara'dia Binuang bersama 30-50 pasukannya menduduki Campalagian pada 23 Agustus 1905. Kondisi itu membuat controleur berangkat ke Campalagian bersama dengan I Mandawari untuk menyelesaikan konflik tersebut. Akhirnya mereka berangkat didampingi pasukan dari Majene. Hasilnya dicapai kesepakatan bahwa I Sendjata tidak akan mengganggu pemerintahan di Campalagian (D.v.O in N.I. 1916:368). 
Akan tetapi, I Sendjata mengumpulkan massa lebih dari 100 orang untuk melakukan gerakan perlawanan atas kekuasaan Belanda di Campalagian pada 22 November 1905 (D.v.O in N.I. 1916:368). Hal tersebut dilakukan oleh I Sendjata karena masih merasa pengangkatan Rammang tidak sesuai adat yang berlaku dan kedudukan pasukan Belanda di Campalagian mengintervensi rakyat.

Aksi itu kemudian ditanggapi oleh pemerintah Hindia Belanda dengan mengirim ekspedisi itu dipimpin oleh Letnan Gusdorf bersama 50 orang pasukan dan mendarat di Campalagian menggunakan kapal H.M. Assahan pada 22 November 1905 (D.v.O in N.I. 1916:369). Kedatangan pasukan Belanda di Campalagian adalah untuk menangkap I Sendjata yang terangterangan menolak pengangkatan Rammang sebagai mara'dia (raja). Satu detasemen pasukan yang dipimpin oleh Letnan Gusdorf tidak membuahkan hasil karena I Sendjata tidak tertangkap dan berhasil menyingkir ke dalam hutan (Hanoch 2006:39).

Sikap Belanda yang menurunkan satu detasemen pasukan untuk menangkap I Sendjata pada 1905 merupakan sebuah cerminan bahwa wilayah ini masih tidak aman bagi Belanda. Tindakan represif harus dilakukan oleh Belanda.

Penempatan seorang controleur juga merupakan usaha sistematis Belanda untuk mengamankan wilayah ini. Tidak hanya sampai di situ saja, Belanda kemudian melakukan pendekatan ke Kerajaan Binuang. Belanda melakukan pendekatan diplomatis dengan melakukan perundingan.

Kerajaan Balanipa dalam periode itu sudah menolak Belanda untuk membujuk I Sendjata agar menyerah, lalu kemudian meminta kepada Kerajaan Binuang untuk membujuk Kerajaan Balanipa agar memerintahkan I Sendjata untuk menyerahkan diri. Usaha tersebut akhirnya berhasil dan I Sendjata akhirnya menyerahkan dirinya (ANRI 1905: No. 476).

I Sendjata awalnya menolak bujukan dari Kerajaan Balanipa kemudian Belanda mengambil tindakan keras dengan melakukan ancaman pembakaran Kampung Campalagian. Kondisi ini membuat I Sendjata terpojok dengan mempertahankan gerakannya tetapi kampung dan rakyat tidak bersalah akan menjadi korban. Di sisi lain, Kerajaan Balanipa tidak menunjukkan dukungan kepada I Sendjata. Tidak adanya dukungan itu disebabkan oleh kontrak yang telah disepakati antara Belanda dan Kerajaan Balanipa. Kontrak ${ }^{5}$ tersebut membuat Kerajaan Balanipa sebagai pemimpin

\footnotetext{
${ }^{5}$ Kontrak-kontrak Kerajaan Balanipa sebagai wakil Mandar yang sudah terjadi sejak 1850 (Karim 2018:6) berisi kesepakatan Mandar untuk menjadi bagian dari pemerintah Hindia Belanda. Kontrak yang memuat kerja sama dalam mengatasi pembajakan kapal-kapal Belanda yang dijarah oleh bajak laut menunjukkan bahwa Mandar dalam hal ini Balanipa sudah berada di lingkaran Belanda (secara tidak langsung). Jarak yang cukup jauh dengan periode perlawanan I Sendjata, maka sangat wajar dalam periode itu Kerajaan
} 
kerajaan-kerajaan Mandar tidak dapat berbuat banyak.

Pada 10 Desember 1905 I Sendjata dikejar oleh Pasukan Belanda sampai ke Lampoko, namun gagal. Mereka kemudian membakar sebuah rumah yang diduga milik Sendjata (D.v.O in N.I. 1916:370). Kasus seperti ini dihindari oleh beberapa pejabat kerajaan karena dapat mennyebabkan jatuhnya korban yang tidak bersalah. Mereka, sebagaimana I Sendjata, kemudian menempuh jalan diplomasi agar tidak menyebabkan korban lebih banyak meski jalan diplomasi juga berisiko karena tidak ada jaminan bahwa Belanda akan bersikap "lembut" kepada rakyat.

Jalan diplomasi I Sendjata berupa penyerahan diri secara sukarela pada 31 Mei 1906. sikap tersebut ditempuh untuk melindungi rakyat di Kerajaan Balanipa. Menyerahnya I Sendjata bermaksud untuk menyelamatkan kampungnya yang diancam dibakar. Ia tidak dipenjara, tetapi diizinkan untuk menetap di Campalagian dengan syarat membayar denda f 500 (D.v.O in N.I. 1916:374).

Sebagaimana I Sendjata, sikap Mandawari dilatari oleh ketakutan akan jatuhnya korban. Kapal perang Belanda membombardir beberapa wilayah Mandar, namun Pambusuang pada saat itu selamat dari serangan karena I

Balanipa tidak memiliki kekuatan yang cukup untuk melawan Belanda. Belum lagi kontrakkontrak lain yang disepakati oleh Mandar setelah 1850 membuat kekuasaan Balanipa mulai melemah.
Vol. 3, No. 2, Juni 2020, hlm. 189-214

Mandawari berhasil melakukan diplomasi dengan pihak Belanda (Syah 1992:95-96). Kondisi itu menunjukkan bahwa sikap diplomatis juga sangat dibutuhkan untuk menghindari jatuhnya korban. Dengan kata lain, sikap diplomatis I Mandawari menyelamatkan rakyat dan kediamannya sendiri di Pambusuang. Peristiwa itu terjadi ketika I Mandawari menjabat sebagai Mara'dia Balanipa untuk kedua kalinya.

Kebijakan Belanda dilatarbelakangi oleh upaya diplomasi yang dilakukan oleh Mandawari. I Sendjata seharusnya dipenjara dan diasingkan ke luar wilayah Mandar tetapi hal itu tidak terjadi. Kondisi itu tentu saja dipengaruhi oleh sebuah upaya diplomatis I Mandawari bukan hasil dari jalan konfrontasi.

Mandawari terhitung tiga kali menjabat sebagai raja Balanipa. Pada periode jabatan ketiga kalinya, I Mandawari mengalami konflik dengan Ammana I Wewang. Hal itu juga disebabkan oleh sikap I Mandawari yang cenderung berada di pihak Pemerintah Hindia Belanda. Adapun Ammana I Wewang, menolak bekerja sama dengan Belanda. Penolakan itu terwujud dalam perjuangannya melawan Belanda.

\section{b. Perlawanan Ammana I Wewang di Mandar}

Ekspedisi militer Belanda berlanjut dan gerakan I Sendjata praktis terhenti karena memilih untuk menyelamatkan rakyatnya dan menyerahkan diri. 
Ekspedisi militer Belanda terus berlanjut karena Belanda belum menangkap tokoh perlawanan lainnya. Tokoh yang dimaksud adalah I Calo Ammana I Wewang.

Ammana I Wewang adalah bangsawan dari Alu (wilayah Kerajaan Balanipa) dan merupakan sepupu dari Tokape. Konflik awal muncul yakni perselisihan antara I Mandawari dengan Ammana I Wewang. Konflik kedua kubu ini awalnya masih senyap, hal itu terkait dengan sikap I Mandawari yang selalu berada di pihak Belanda. Terlebih lagi, I Mandawari juga pernah berkonflik dengan Tokape. Kemudian, momen Ekspedisi Militer Belanda membuat konflik tersebut muncul ke permukaan. Kondisi ini tentu saja sangat menguntungkan pemerintah Hindia Belanda untuk melaksanakan strategi politik devide et impera (adu domba).

I Mandawari pada akhirnya bekerjasama dengan Belanda. Keduanya memiliki kepentingan, I Mandawari masih ingin menjadi Raja Balanipa dan Belanda ingin menangkap Ammana I Wewang sebagai pemimpin dari pasukan perlawanan rakyat Mandar karena menolak untuk dikuasai secara penuh oleh pemerintah Hindia Belanda.

Perjuangan Ammana I Wewang dimulai dari gerakan penentangan atas kedatangan pasukan Belanda di Alu. Besarnya perjuangan itu, nampak dari pemberitaan koran-koran Belanda yang menyatakan bahwa gerakan cukup besar. Ammana I Wewang dikenal sebagai pemimpin pasukan yang sangat ditakuti karena cukup mengacaukan gerakan-gerakan ekspedisi militer Belanda. Dia juga berhasil menghimpun masyarakat dan membentuk pasukan yang cukup besar (Seoerabaiasch-Handelsblad 1906:1).

Gerakan paling sukses Ammana I Wewang dan pasukannya yakni menyerang kantor controleur di Majene pada 6 Juni 1906. Hasilnya, Pasukan Ammana I Wewang menguasai Majene dan menangkap juru tulis Belanda atas nama Schidthamer dan dibawa ke hutan. Dhomen sebagai controleur Mandar berhasil kabur ke Pare-Pare dengan menggunakan perahu (ANRI 1907:65).

Gerakan selanjutnya terjadi pada 12 Juni 1906. Pasukan Mandar berhasil merebut kapal H.M. Siboga. Pemerintah Hindia Belanda akhirnya menyatakan bahwa yang bertanggung jawab dalam peristiwa tersebut adalah Katjopoeng dan I Calo Ammana I Wewang (Anon 1906b:1).

Tujuan gerakan yang dilakukan oleh Pasukan Ammana I Wewang adalah untuk melemahkan posisi pemerintah Hindia Belanda di Mandar. Dimulai dengan penyerangan kantor perwakilan pemerintahan Belanda di Majene lalu merebut kapal H.M. Siboga agar wilayah pelabuhan juga dapat dikuasai. Dengan begitu, akses politik dan ekonomi Belanda praktis tertutup. Penguasaan pelabuhan juga merupakan salah satu jalan untuk menutup akses distribusi Belanda, baik itu distribusi pasukan maupun logistik. Tetapi usaha 
rakyat Mandar mempertahankan pendudukan pelabuhan tidak berlangsung lama karena pasukan Belanda bersikeras sangat gigih untuk merebut Majene dan Pelabuhannya dari Pasukan Ammana I Wewang. Akhirnya pasukan Ammana I Wewang berhasil dipukul mundur.

Berikutnya, Belanda kemudian bertindak lebih keras dengan mengirim ekspedisi militer gelombang ke dua dan menyasar wilayah basis pasukan Ammana I Wewang. Berikut kutipan dari (D.v.O in N.I. 1916:375).

"Pada tanggal 13 Juni Kapten Lensoek Berangkat ke Balanipa dengan jumlah pasukan 57 orang. Tujuan utama dari pasukan ini adalah menuju Alu dan dalam perjalanan, mereka dihujani tembakan senapan di perkirakan jumlah pasukan yang menyerang sekitar 300 orang lokasinya berada tepat di Tepian sungai Balanipa (Mandar), serangan itu mengakibatkan 12 orang luka-luka dan kapten pasukan memutuskan untuk kembali ke arah selatan menuju Napo. Selama serangan itu pasukan Mandar juga menderita 7 orang luka-luka. Mendengar kondisi yang dialami oleh Kapten Lenshoek, Asisten Residen Vermeulen mengirim surat ke Makassar dan meminta untuk mengirimkan pasukan dari Makassar. Batalion ke-8 pun diberangkatkan, dan pasukan ini sebenarnya merupakan pasukan cadangan yang di peruntukan untuk menjaga wilayah Makassar.

Peristiwa 13 Juni menunjukkan bahwa Ammana I Wewang dan pasukannya berhasil dipukul mundur ke wilayah basis pertahanan mereka. Kekalahan para pejuang Mandar tetapi membuat semangat perjuangan semakin berkobar. Di sisi lain, ekspedisi yang dilakukan oleh Kapten Lenshoek merupakan kondisi yang menunjukkan bahwa perlawanan Pasukan Ammana I Wewang masih berjalan dan tidak pernah berhenti. Belanda bahkan semakin khawatir dengan memberangkatkan Batalion cadangan dari Makassar. Bagi Belanda, Mandar masih menjadi wilayah mencekam.

Pasukan Lenshoek akhirnya mundur ke Napo karena tidak dapat menguasai medan pertempuran di wilayah Alu (basis pertahanan pasukan Mandar) yang berupa pegunungan dan hutan. Lanshoek kemudian memilih jalan pulang melalui Sungai Balanipa. Pasukan Belanda menyusuri sungai meninggalkan medan pertempuran dan menuju Tinambung. Langkah itu ditempuh oleh Lanshoek agar tidak menjadi sasaran empuk Pasukan Mandar yang menguasai medan pertempuran di pedalaman hutan.

Pasukan Ammana I Wewang (Mandar) pada waktu itu berada di atas angin. Lanshoek tidak berhasil Alu. Usahanya berikurnya adalah dengan meminta pasukan tambahan dari Makassar. Pemerintah Hindia Belanda akhirnya menyetujui permintaan Lanshoek dan mengirim pasukan dari Makassar.

Ekspedisi militer gelombang ketiga akhirnya dilancarkan oleh Belanda. Pasukan yang dipimpin oleh Mayor Lanzing tiba di Majene pada 19 Juni 1906. Dua hari kemudian, tepatnya 21 
Juni 1906 terjadi kontak senjata antara Pasukan Ammana I Wewang dengan pasukan Lanzing di Majene (D.v.O in N.I. 1916:376).

Lanzing dan pasukannya mengalami kesulitan menghadapi Pasukan Ammana I Wewang. Kesulitan Lanzing akhirnya terbayar dengan berhasil memukul mundur pasukan Mandar pada 26 Juni 1906 (ANRI 1907:66). Meskipun Pasukan Ammana I Wewang berhasil dipukul mundur, Ammana I Wewang tidak berhasil ditangkap dan kembali menyingkir ke dalam hutan.

Pasukan Ammana I Wewang tidak begitu diuntungkan dengan kondisi tersebut karena Belanda yang memiliki pasukan dan pasokan logistik yang cukup untuk mempertahankan Majene. Terlebih lagi, situasi Majene tidak lagi mencekam seperti yang terjadi sebelum kedatangan Lanzing. Kondisi itu kemudian diperparah dengan wafatnya beberapa Pasukan Ammana I Wewang. Kontak senjata yang terjadi pada 19-26 Juni 1906 memakan tujuh belas korban dari pasukan Mandar. Salah satu korban tersebut adalah kakak dari Ammana I Wewang (Hanoch 2006:44).

Kapten Lenshoek pada 30 Juni hingga 2 Juli melakukan patroli dan menaklukkan beberapa wilayah yang menjadi basis perlawanan rakyat Mandar. Pasukan itu berhasil menyisir wilayah Tundung, Sungai Balanipa, Galung, Simulau, Baruga, Batu me'appar, Pu'awang dan kembali ke Majene (D.v.O in N.I. 1916:378). Tujuan patroli itu adalah melanjutkan pengejaran dan menangkap Pasukan Ammana I Wewang yang berhasil mundur pada pertempuran sebelumnya.

Pasukan Lanzing juga harus mundur karena kondisinya medan tempur yang tidak menguntungkan bagi Pasukan Belanda. Di sisi lain, pihak Ammana I Wewang juga tidak dapat bertahan lebih lama. Kekuatan militer mereka sudah sangat berkurang, ditambah lagi, di pihak lain, pasukan Belanda memperoleh suplai senjata yang memadai. Pilihan untuk melakukan kontak senjata dengan tentara Belanda cukup berat dan pada akhirnya Pasukan Ammana I Wewang memilih untuk mengamankan pasukan lainnya.

Pasukan Ammana I Wewang akhirnya bergeser ke Pamboang tepatnya di Adolang (Anon 1906a:1). Pasukan Belanda mengetahui pergerakan pasukan tersebut sehingga kemudian melakukan pengejaran ke Adolang pada 6 Juli 1906 . Hasilnya yakni mereka menemukan Pasukan Ammana I Wewang berada di sebuah perbukitan. Pada pukul delapan pagi terjadi kontak senjata dan diperkirakan Pasukan Ammana I Wewang berjumlah tidak lebih dari 20 orang. Pada akhirnya, pasukan Mandar dipukul mundur dengan 13 orang tewas dan pasukan Belanda berhasil merebut tujuh pucuk senjata dan amunisi (D.v.O in N.I. 1916:379).

Benteng Adolang diduduki, tetapi Belanda tidak berhasil menangkap pimpinan pasukan Ammana I Wewang. Mereka berhasil menguasai jalur 
pengamanan pasukan sebelum Belanda mencapai puncak Benteng Adolang. Jatuhnya benteng ini ke tangan Belanda merupakan pukulan telak bagi pasukan Mandar. Sejak didudukinya Benteng Adolang, pasukan Belanda gencar melakukan patroli di seluruh wilayah Mandar, terutama di wilayah Majene, Pamboang, dan Alu untuk mengejar Ammana I Wewang

Selanjutnya, pada 10 Oktober 1906 "Si Gaang" berhasil ditangkap oleh pasukan Belanda (ANRI 1907:66). Si Gaang merupakan mantan mara'dia Alu yang merupakan ayah dari Katjoepoeng dan I Calo Ammana I Wewang. Pasukan Belanda lagi-lagi tidak berhasil menangkap Ammana I Wewang dan hanya berhasil menangkap ayahnya. Segala cara telah ditempuh oleh Belanda untuk menangkap Ammana I Wewang. Pada akhirnya Belanda meminta bantuan kepada I Mandawari dan I Laju Kakanna I Doro.

Taktik baru ditempuh oleh Belanda dengan mencari informasi terkait kebiasaan Ammana I Wewang. Salah satunya adalah Ammana I Wewang sering dipijat oleh salah satu kenalannya di Tandasura. I Laju Kakanna I Doro mengetahui tukang pijat dari Ammana I Wewang. Berikutnya Belanda mengiming-imingi imbalan $f 1000$ apabila menunjukkan persembunyian Ammana I Wewang. Pada 23 Juli 1907 Ammana I Wewang berhasil ditangkap saat tertidur pulas di tempat persembunyiannya (Yasil 2012:126).
Ammana I Wewang akhirnya dikenakan hukuman 20 tahun penjara (Yasil 2012:126) dan diasingkan ke Belitung, Tanjung Pandang bersama sisa pasukannya yang tertangkap Ammana I Wewang sebagai (Swart 1908:14) (ANRI 1908: Kolonial Verslag 1908: 60). Ammana I Wewang dijatuhi hukuman pengasingan, bukan hukuman mati agar tidak menyulut pemberontakan di Mandar.

Pilihan mengasingkan Ammana I Wewang juga merupakan keputusan yang cukup tepat bagi Belanda. Hal itu juga dilakukan kepada Tokape yang diasingkan ke Pacitan (Hanoch 2006:41). Jalan pengasingan dinilai pemerintah kolonial cukup efektif karena dibutuhkan beberapa dekade untuk melahirkan penerus Mandar yang berani melakukan perlawanan kepada Belanda.

Akibatnya, kondisi itu memaksa Mandar jatuh ke tangan Pemerintah Hindia Belanda secara utuh. Tertangkapnya Ammana I Wewang merupakan akibat dari konflik internal yang terjadi di Kerajaan Balanipa (wakil Mandar). Adanya perebutan kekuasaan di Kerajaan Balanipa yang melibatkan kubu Ammana I Wewang dan I Mandawari berdampak bocornya informasi terkait gerakan pasukan Ammana I Wewang. I Mandawari memberikan informasi terkait akses untuk menembus pertahanan pasukan Ammana I Wewang yang pada awalnya sulit dijangkau karena medannya cukup berat. 


\section{Ekspedisi Militer Belanda Berhasil Menaklukkan Mandar}

Tertangkapnya Ammana I Wewang menjadi pertanda bahwa Mandar benarbenar takluk di hadapan Pemerintah Hindia Belanda. Berbeda dengan Ammna I Wewang yang akhirnya memperoleh hukuman pengasingan, I Mandawari menjadi raja yang "diakui" oleh Belanda dan menandatangani perjanjian pendek dengan pihak pemerintah kolonial.

Kontrak Pendek (Korte Verklaring) tersebut ditandatangani pada 2 Agustus 1906 (ANRI 1906:No.662). Kontrak tersebut berisi tentang pengakuan terhadap pemerintah kolonial Belanda dan diangkatnya Mandawari sebagai mara'dia (raja) Balanipa. Selain itu, Kerajaan Balanipa sebagai wakil Mandar harus membayar ganti rugi dan membayar pajak kepada Belanda. Kemudian diangkatlah controleur bernama Dhomen (D.v.O in N.I. 1916:336).

Selanjutnya pada 1907 Mandar dilepaskan dari wilayah administrasi Afdeling Pare-Pare dan diusulkan untuk membentuk Afdeling Mandar (Vorstman 1924:22). I Laju Kakanda I Doro yang menggantikan Mandawari sebagai mara'dia juga menandatangani Korte Verklaring pada 2 November 1909 (ANRI 1909:No. 663). Berikutnya pada 1909, Afdeling Mandar terbentuk dan berdasarkan keputusan Pemerintah Hindia Belanda tanggal 5 Juli 1909 No.17, pemerintahan Belanda berjalan secara resmi di bawah pemerintahan L.J.J. Carou. Majene dipilih sebagai Ibu
Kota Afdeling Mandar. Sejak saat itu, secara administratif Mandar telah dikuasai secara penuh oleh pemerintah Hindia Belanda (ANRI 1910:265). Kondisi itu praktis mengubah status Mandar dari negara sekutu menjadi negara bawahan. Pax Neerlandica akhirnya tercapai.

\section{SIMPULAN}

Ekspedisi Militer Belanda yang dilakukan pada 1905-1907 merupakan salah satu upaya untuk melaksanakan proyek desentralisasi. Tujuan utamanya adalah penguasaan penuh atas wilayahwilayah di Hindia Belanda yang statusnya masih sebagai negara sekutu, termasuk kerajaan-kerajaan di Sulawesi.

Mandar menjadi salah satu wilayah yang statusnya ingin diubah dari negara sekutu menjadi negara bawahan. Oleh karena itu, Pemerintah Hindia Belanda menjalankan ekspedisi militer ke Mandar pada 1905. Tindakan Belanda kemudian memicu rakyat Mandar melakukan gerakan perlawanan karena tidak ingin tunduk pada Pemerintah Hindia Belanda.

Ekspedisi gelombang pertama dipimpin oleh Gusdorf pada 22 November 1905 dan terjadi perlawanan yang dipimpin oleh I Sendjata. I Sendjata adalah salah satu pemimpin rakyat Campalagian yang menolak kedatangan Belanda. Perlawanan tersebut pada akhirnya dapat diredam oleh Belanda dengan melancarkan strategi-strategi militer. Salah satu strategi yang dilakukan 
Belanda adalah dengan membakar rumah dan mengancam I Sendjata. Ancaman akan membakar Campalagian apabila I Sendjata tidak menyerahkan diri, membuatnya menyerah dan dijatuhi hukuman penjara.

Ekspedisi gelombang kedua yang dipimpin oleh Kapten Lanshoek pada 13 Juni 1906 dan terjadi perlawanan yang dipimpin oleh I Calo Ammana I Wewang. Gerakan tersebut merupakan gerakan terbesar orang Mandar dalam usahanya menentang Belanda. Awalnya, pasukan Mandar berhasil memukul mundur pasukan Belanda dan membuat mereka kerepotan bahkan Belanda mengalami kerugian yang cukup besar.

Kondisi itu memaksa Belanda untuk mengirim ekspedisi gelombang ketiga. Pasukan itu merupakan pasukan tambahan yang dipimpin oleh Mayor Lanzing pada 19 Juni 1906. Belanda harus mengirim tiga gelombang pasukan. Akan tetapi, peralatan dan jumlah pasukan Belanda yang cukup banyak perlawanan Ammana I Wewang akhirnya dapat diredam dan Ammana I Wewang juga tertangkap.

Berakhirnya perlawanan rakyat Mandar tidak terlepas dari peran bangsawan lain yang berada di pihak Belanda. Dengan kata lain, terjadi kontestasi dalam peristiwa penaklukan Mandar. Kontestasi itu melibatkan bangsawan yang melawan Belanda dan memilih untuk tidak melawan.

I Sendjata dan Ammana I Wewang memilih untuk melawan Belanda dan
I Mandawari lebih memilih untuk berdiplomasi Belanda dengan pertimbangan rakyat Pambusuang akan aman dari serangan Belanda.

Keputusan itu harus dibayar oleh I Mandawari dengan membocorkan segala informasi tentang gerakan Ammana I Wewang dan I Sendjata. Selain itu, I Mandawari juga memperoleh keuntungan yakni dia diangkat menjadi mara'dia (raja) oleh Belanda.

Periode Perjuangan I Sendjata (dan Ammana I Wewang) merupakan periode yang mempertemukan dua jalan dalam melawan penjajah. Antara jalan perjuangan konfrontasi dan diplomasi. Sikap penyerahan diri I Sendjata dapat digolongkan sebagai langkah diplomasi yang dipengaruhi oleh perjuangan diplomasi I Mandawari sebagai Raja Balanipa. Sikap Mandawari yang tampaknya "pro" kepada Belanda membuat stigma yang terbangun pada zaman itu mengarah pada "pengkhianatan" seorang raja.

Akhirnya ekspedisi militer, perlawanan rakyat dan pertentangan elite lokal juga diwarnai perebutan tahta raja di Kerajaan Balanipa. Hasilnya adalah pihak Mandar kalah dan sistem pemerintahan juga ikut berubah karena Belanda berhasil mengubah status Kerajaan Balanipa serta sekutunya menjadi negara bawahan.

Kondisi tersebut menunjukkan bahwa proyek desentralisasi oleh Pemerintah Hindia Belanda praktis berhasil diterapkan dan cita-cita 
efisiensi dan otonomi Pemerintah Hindia Belanda dapat dicapai. Sistem pemerintahan akhirnya bersifat tunggal di seluruh wilayah Mandar bahkan Sulawesi. Otomatis cita-cita Pax Neerlandica dapat dicapai oleh pemerintah Hindia Belanda.

\section{DAFTAR SUMBER}

Ali, Ismail. 2014. Ketuanan Bajak Laut Suku Mandar di Laut Celebes dan Reaksi Kolonial Belanda pada Abad Ke-19. Diunduh Oktober, 2019 (https:// docplayer.net/48367374Universiti-malaysia-sabah-2014isbn-proceedings-of-the-1-stinternational-maritime-conference1 - st - imc 2014 - october- 21 2014.html).

Amir, Muhammad. 2017. "Gerakan Petta Barang di Daerah Bugis pada 1906-1913." Al-Qalam 23(2): 209-222.

. 2018. Perlawanan Sawitto Terhadap Belanda di Sulawesi Selatan Pada 1905-1906. Walasuji 9(1):1-21.

Anon. 1906a. "De Preanger-Bode." No.293, December 17, 1.

Anon. 1906b. "Haagsche Courant." No. 7193, August 11, 1.

ANRI. 1906. Kontrak Balanipa No 662.

ANRI. 1907. Kolonial Verslag.

ANRI. 1908. Kolonial Verslag.
ANRI. 1909. Kontrak Balanipa, No. 663.

ANRI.1905. Vervolg op Dezerzijdsche Geheim Massive 15 December, No. 476.

ANRI. 1910. Regeerings Almanak voor Nederlandsch-Indie.

Boom, C.N. 1912. Nota van Toelichting Betreffende het Landschap Balangnipa. Batavia: Albrecht \& Co.

Dienst van Oorlog in Nederlandsch Indie. 1916. Indisch Militair Tijdschrift. De Expeditie naar Zuid-Celebes in 1905-1906, Eerste Gedeelte de actie in Gowa, Adjataparang en Masenrempoeloe en in Mandar. BataviaWeltevreden: G. Kolff \& Co.

Furnivall, J. S. 2009. Hindia Belanda/ Studi tentang Ekonomi Majemuk. Jakarta: Freedom Institute.

Hanoch, Luhukay. 2006. Memori Asisten Residen W.J. Leids Selama Bertugas di Mandar. Makassar: Yayasan Kaitupa.

Karim, Abd. 2018. Jatuhnya Kerajaan Balanipa: Penataan Wilayah Mandar 1905-1942. Jakarta: Direktorat Sejarah, Kementrian Pendidikan dan Kebudayaan. 2018. "Political Contestation, Political Elite Contestation of Balanipa Kingdom and Netherland Colonial Government in 18701905." IJPSLIR International 
Journal of Political Science, Law and International Relations 8(1):1-10.

. 2019. "Lontara' Pattodioloang sebagai Sumber Sejarah Mandar 1850-1905.” Abad: Jurnal Sejarah 03(2):5-17.

Kartodirdjo, Sartono. 1973. Ikhtisar Keadaan Politik Hindia-Belanda Tahun 1839-1848. Arsip Nasional Republik Indonesia.

Laely, N.2018. Sistem Pemerintahan Kolonial Hindia Belanda di Onderafdeling Bonthain 19051942. Disertasi, Universitas Negeri Makassar.

Latif, Abd. 2014. "Diplomasi Dan Ekspedisi Militer Belanda Terhadap Tiga Kerajaan Lokal Di Sulawesi Selatan 1824-1860." Sosiohumanika 7(2):159-174.

Locher-Scholten, Elsbeth. 1994. "Dutch Expansion in the Indonesian Archipelago around 1900 and the Imperialism Debate." Journal of Southeast Asian Studies 25(1):91-111.

Michielsen, A.W.A. 1915. Indisch Militair Tijdschrift. De Expeditie Naar Zuid-Celebes in 1905-1906. Batavia-Weltevreden:G. Kolff\&Co.

Mirawati, Ina. 2013. "Dari Perahu Sri Komala Hingga Puputan; Perlawanan Terhadap Pemerintahan Hindia Belanda 1906." Citra Lekha 17(1):33-42.
Muhajir, Ahmad. 2018. "Langkah Politik Belanda di Aceh Timur: Memahami Sisi Lain Sejarah Perang Aceh, 1873-1912." Mukadimah: Jurnal Pendidikan, Sejarah, dan Ilmu-Ilmu Sosial 1(2):160-71.

Poelinggomang, Edward L. 2012. Sejarah dan Budaya Sulawesi Barat. Makassar: Balai Pelestarian Nilai Budaya Makassar-De Lamacca.

Rahmatullah. 2018. Watang Lipu La Palloge dalam Menentang Imperialisme Belanda di Kerajaan Soppeng (1905-1906). Tesis, Universitas Negeri Makassar.

Sinrang, S. 1994. Mengenal Mandar Sekilas Lintas Perjuangan Mandar Melawan Belanda (16671949). Ujung Pandang: Yayasan Kebudayaan Mandar Rewata Rio.

Soerabaiasch-Handelsblad. 1906. "De Aanval op de Kampong Madjene (Mandhar)." SoerabaiaschHandelsblad, 20 Juli.

Southgate, Beverley. 2001. History: What and Why?: Ancient, Modern and Postmodern Perspectives. London: Routledge.

Swart, H. N. A. 1908. Memorie van Overgave.

Syah, Tanawali Aziz. 1992. Lontarak 2 Pattodioloang di Mandar. Ujung Pandang: Taruna Remaja. 
Universitaire Bibliotheken Leiden.

1930. "Automobielkaart van Zuid

Celebes." Diunduh Oktober, 2020

(https://digitalcollections. universiteitleiden.nl/view/item

817268 ? s o lr_nav\% 5 B id\%5D=af5af995e6d996511abf\&

solr_nav $\% 5$ Bpage $\% 5 \mathrm{D}=0 \&$ solr_nav

$\% 5$ Boffset $\% 5 \mathrm{D}=15$ ).

Vorstman, F.C. 1924. Memori van Overgave Gouverneur Celebes en Onderhoorigheeden.

Yasil, Suradi, Banru Talib, dan Muhammad Ridwan. 2012. Naskah Awal Sejarah Polewali Mandar. Polewali Mandar: Dinas Perhubungan, Komunikasi dan Informatika. 
